\title{
Rapid but not Slow Spinal Cord Compression Elicits Neurogenic Pulmonary Edema in the Rat
}

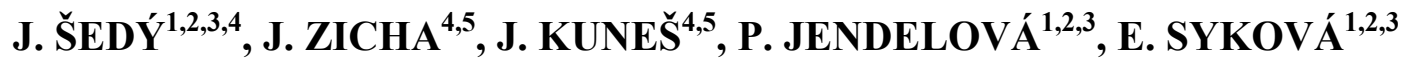 \\ ${ }^{1}$ Institute of Experimental Medicine, Academy of Sciences of the Czech Republic, ${ }^{2}$ Center for Cell \\ Therapy and Tissue Repair, Second Faculty of Medicine, Charles University, ${ }^{3}$ Department of \\ Neuroscience, Second Faculty of Medicine, Charles University, ${ }^{4}$ Institute of Physiology, Academy \\ of Sciences of the Czech Republic, ${ }^{5}$ Center for Cardiovascular Research, Prague, Czech Republic
}

Received January 14, 2008

Accepted February 9, 2008

On-line April 1, 2008

\section{Summary}

The development of neurogenic pulmonary edema (NPE) can be elicited by an immediate epidural balloon compression of the thoracic spinal cord. To evaluate whether a slower balloon inflation could prevent NPE development, we examined the extent of NPE in animals lesioned with a rapid $(5 \mu \mathrm{l}-5 \mu \mathrm{l}-5 \mu \mathrm{l})$ or slow rate $(3 \mu \mathrm{l}-2 \mu \mathrm{l}-2 \mu \mathrm{l}-2 \mu \mathrm{l}-2 \mu \mathrm{l}-2 \mu \mathrm{l}-2 \mu \mathrm{l})$ of balloon inflation. These groups were compared with the NPE model (immediate inflation to $15 \mu \mathrm{l}$ ) and with healthy controls. Slow balloon inflation prevented NPE development, whereas the pulmonary index and histology revealed a massive pulmonary edema in the group with a rapid rate of balloon inflation. Pulmonary edema was preceded by a considerable decrease in heart rate during the inflation procedure. Moreover, rapid inflation of balloon in spinal channel to either $5 \mu \mathrm{l}$ or $10 \mu \mathrm{l}$ did not cause NPE. Thus, a slow rate of balloon inflation in the thoracic epidural space prevents the development of neurogenic pulmonary edema, most likely due to the better adaptation of the organism to acute circulatory changes (rapid elevation of systemic blood pressure accompanied by profound heart rate reduction) during the longer balloon inflation period. It should be noted that spinal cord transection at the same level did not cause neurogenic pulmonary edema.

\section{Keywords}

Neurogenic pulmonary edema $\bullet$ Rat $\bullet$ Spinal cord injury $\bullet$ Blood pressure $\bullet$ Heart rate

\section{Corresponding author}

J. Šedý, Institute of Experimental Medicine, Academy of Sciences of the Czech Republic, Vídeňská 1083, 14220 Prague 4, Czech Republic. Fax: + 420-241062783. E-mail: jirisedy@hotmail.com

\section{Introduction}

Neurogenic pulmonary edema is an acute lifethreatening complication following spinal cord or brain injury (Fontes et al. 2003). It is characterized by marked pulmonary vascular congestion, extravasation of proteinrich edema fluid and intraalveolar hemorrhage (Kandatsu et al. 2005, Kondo et al. 2004, Leal Filho et al. 2005a,b). Many pathophysiological mechanisms have been implicated in the development of neurogenic pulmonary edema, but the exact cascade leading to its development is still unclear (Leah Filho et al. 2005a,b). Both the release of vasoactive substances and a severe transient sympathetic discharge are thought to participate in this process (Taoka and Okajima 1998, Urdaneta and Layon 2003). These processes lead to the constriction of the pulmonary veins, an increase in pulmonary capillary hydrostatic pressure, damage to the alveolar wall and the leakage of fluid into the intraalveolar space (Fontes et al. 2003).

Our previous experiments showed that severe neurogenic pulmonary edema could be experimentally induced by immediate epidural balloon compression of the thoracic spinal cord in the rat, anesthetized by $1.5 \%$ isoflurane in air (Šedý et al. 2007a,b). The aim of this study was to evaluate the extent of neurogenic pulmonary edema development in the case of a gradual inflation of the balloon in the spinal channel. For this purpose, the final balloon inflation volume of $15 \mu \mathrm{l}$ was reached by several greater or numerous smaller steps. In addition, the occurrence of neurogenic pulmonary edema was also 
examined in animals with lower volumes of balloon inflation as well as in those with thoracic spinal cord transection.

\section{Materials and Methods}

Animals

We used 65 male Wistar rats (Velaz, Prague, Czech Republic) with body weight between 300-330 g. This study was performed in accordance with the European Communities Council Directive of 24th of November 1986 (86/609/EEC) regarding the use of animals in research and was approved by the Ethics Committee of the Institute of Experimental Medicine ASCR, Prague, Czech Republic.

\section{Design of the study}

After the induction of anesthesia with $5 \%$ isoflurane in room air (flow $300 \mathrm{ml} / \mathrm{min}$ ), animals were maintained in $1.5 \%$ isoflurane anesthesia (flow $300 \mathrm{ml} / \mathrm{min}$ ) via a face mask throughout the operation. This concentration of isoflurane was previously shown to promote neurogenic pulmonary edema development in rats with immediate balloon compression of the thoracic spinal cord (Šedý et al. 2007a). All animals were heated to $37^{\circ} \mathrm{C}$, and their body temperature was measured by a rectal thermometer to standardize the procedure and to exclude the influence of hypo- or hyperthermia (Cambria et al. 1997, Urdziková and Vanický 2006). A catheter was inserted into the common carotid artery to monitor blood pressure and heart rate changes. After the insertion of the catheter, an epidural balloon spinal cord compression lesion (Vanický et al. 2001) or complete Th8 transection was performed. The animal was left to recover for $10 \mathrm{~min}$ and then was sacrificed. The lungs were immediately removed and analyzed for the presence of neurogenic pulmonary edema. Controls were animals without spinal cord injury, sacrificed immediately after the onset of anesthesia.

\section{Balloon compression spinal cord lesion}

To induce a spinal cord injury we used the model of an epidural balloon compression lesion (Vanický et al. 2001), as described previously (Šedý et al. 2007a). Briefly, under aseptic conditions, a $2 \mathrm{~cm}$ median skin incision at the Th10-L1 level was made. The dorsal muscles were shifted laterally, and the Th10 and Th11 spinous processes were removed. A hole was drilled into the Th10 lamina with a dental drill. Then, a
2F French Fogarthy catheter (Baxter Healthcare Corporation, Irvine, CA, USA), which was filled with distilled water and connected to a 50- $\mu$ l Hamilton syringe, was inserted into the dorsal epidural space $10 \mathrm{~mm}$ rostrally, to reach the Th8-Th9 spinal level. Using a micromanipulator, the balloon was inflated with a rapid $(5 \mu \mathrm{l}-5 \mu \mathrm{l}-5 \mu \mathrm{l})$ or a slow rate of inflation $(3 \mu \mathrm{l}-2 \mu \mathrm{l}$ $2 \mu \mathrm{l}-2 \mu \mathrm{l}-2 \mu \mathrm{l}-2 \mu \mathrm{l}-2 \mu \mathrm{l})$ or in the standard NPE model immediately to $15 \mu \mathrm{l}$. In all cases, the final volume of the balloon was $15 \mu \mathrm{l}$. The time window between each step of the inflation was $30 \mathrm{~s}$. Thus, the entire balloon inflation procedure lasted one minute during rapid inflation and $3 \mathrm{~min}$ during slow inflation. As an additional experiment, we also inflated the balloon immediatelly to either $5 \mu \mathrm{l}$ or $10 \mu \mathrm{l}$. After inflation to the final volume, the balloon was left in place for $5 \mathrm{~min}$ in all cases. Subsequently, the balloon was deflated and removed.

The immediate inflation of the balloon in the epidural space of the thoracic spinal channel with $15 \mu \mathrm{l}$ of distilled water under $1.5 \%$ isoflurane anesthesia reliably and reproducibly produces severe neurogenic pulmonary edema (Šedý et al. 2007a,b). We therefore used this model for comparison with the other groups in this experiment. The inflation of a balloon to $15 \mu \mathrm{l}$ in the spinal channel produces an incomplete lesion, so that after 7 weeks, the hindlimbs of the animals are able to support body weight and occasionally forelimb-hindlimb coordination is observed. This state corresponds to a BBB locomotor score (Basso et al. 1995) of 9-11 at 7 weeks post-injury (Vanický et al. 2001; Šedý et al. 2007a). To verify the injury procedure, the balloon was inflated before and immediately after the injury procedure outside of the animal to confirm the inflation of the balloon in the spinal channel. The design of the study did not allow in vivo verification of the lesion by imaging or behavioral testing methods.

\section{Spinal cord transection}

A complete Th8 spinal cord transection was performed in animals anesthetized with $1.5 \%$ isoflurane in order to evaluate the role of a thoracic spinal cord lesion per se in neurogenic pulmonary edema development. Briefly, under aseptic conditions, a $2 \mathrm{~cm}$ median skin incision at the Th6-8 level was made. The dorsal muscles were cut and shifted laterally, and the Th7 lamina was removed. After that, a rapid spinal transection was performed by a sharp razor blade. 
Table 1. The impairment of lung function after spinal cord injury in the NPE model as well as in animals with a gradually compressed spinal cord, incompletely compressed spinal cord ( 5 or $10 \mathrm{ul}$ only) or a spinal transection.

\begin{tabular}{|c|c|c|c|c|c|c|}
\hline Group & $\mathbf{N}$ & $\begin{array}{c}\text { Absent } \\
\text { (\% of } 2 \mathrm{~N})\end{array}$ & $\begin{array}{c}\text { Grade I } \\
(\% \text { of } 2 \mathrm{~N})\end{array}$ & $\begin{array}{c}\text { Grade II } \\
(\% \text { of } 2 N)\end{array}$ & $\begin{array}{l}\text { Grade III } \\
(\% \text { of } 2 N)\end{array}$ & $\begin{array}{l}\text { Pulmonary } \\
\text { index }\end{array}$ \\
\hline $\begin{array}{l}\text { NPE model } \\
(15 \mu l)\end{array}$ & 19 & - & - & $\begin{array}{c}1 \\
(3 \%)\end{array}$ & $\begin{array}{c}37 \\
(97 \%)\end{array}$ & $0.86 \pm 0.09^{*}$ \\
\hline $5-5-5 \mu l$ & 7 & - & - & $\begin{array}{c}6 \\
(43 \%)\end{array}$ & $\begin{array}{c}8 \\
(57 \%)\end{array}$ & $0.77 \pm 0.08^{*}$ \\
\hline $3-2-2-2-2-2-2 \mu l$ & 14 & $\begin{array}{c}18 \\
(64 \%)\end{array}$ & $\begin{array}{c}10 \\
(36 \%)\end{array}$ & - & - & $0.49 \pm 0.03$ \\
\hline Immediate $5 \mu \mathrm{l}$ & 3 & $\begin{array}{c}6 \\
(100 \%)\end{array}$ & - & - & - & $0.46 \pm 0.04$ \\
\hline Immediate $10 \mu l$ & 3 & $\begin{array}{c}6 \\
(100 \%)\end{array}$ & - & - & - & $0.46 \pm 0.03$ \\
\hline $\begin{array}{l}\text { Spinal } \\
\text { transection }\end{array}$ & 5 & $\begin{array}{c}10 \\
(100 \%)\end{array}$ & - & - & - & $0.43 \pm 0.06$ \\
\hline Control & 14 & $\begin{array}{c}28 \\
(100 \%)\end{array}$ & - & - & - & $0.45 \pm 0.02$ \\
\hline
\end{tabular}

The absence or presence of subpleural bleeding (evaluated as Grade I-III) in different groups is given as the total number of lungs in each group (the right and left lung were considered separately) and the percentage of all lungs examined in the respective group. A significant elevation $(p<0.05)$ of the pulmonary index (mean \pm S.E.M.) in comparison with controls is indicated by an asterisk. Control animals are animals without spinal cord injury, sacrificed immediately after the onset of anesthesia. $\mathrm{N}$ - number of rats, $2 \mathrm{~N}$ - number of lungs.

\section{Evaluation of neurogenic pulmonary edema}

The lungs were immediately removed from sacrificed animals and weighed. In all cases, a mild hematoma, maximally $1 \mathrm{~mm}$ in diameter, was found in the hilus area due to the manipulation of the pulmonary vessels during lung removal (not taken into further account). The level of pulmonary subpleural bleeding was evaluated macroscopically as "Absent" (no bleeding on the lung surface), "Grade I" (small bleeding areas, occupying not more than $10 \%$ of the lung surface), "Grade II" (medium-sized bleeding areas, occupying $11-50 \%$ of the lung surface) and "Grade III" (massive bleeding areas, occupying more than $50 \%$ of the lung surface), as described previously (Šedý et al. 2007a,b). Each lung was evaluated separately. To estimate the liquid accumulation in the lungs, both lungs were weighed, and the relative pulmonary weight was calculated as the pulmonary index (lung weight/body weight $\mathrm{x} 100$ ), which has been previously considered to be very sensitive indicator of the degree of pulmonary edema (Leal Filho et al. 2005a,b, Mesquita et al. 2002, Minnear and Connel 1982, Šedý et al. 2007a). The lungs were immediately fixed in $4 \%$ paraformaldehyde in phosphate buffer $(\mathrm{pH}$ 7.4) for 2 days, embedded in paraffin, cut in $5 \mu \mathrm{m}$ sections and stained with hematoxylin and eosin. The thickness of the alveolar walls was measured using Neurolucida software (MicroBrightField, Inc., USA). From each lung, three sections (from the inferior, middle and superior parts of the lung) were taken, and alveolar wall thickness in one representative field from each section was measured. A representative field was defined as a site in the nonsubpleural lung parenchyma, without any large vessel or bronchus, outside of the hilus region.

\section{Measurement of blood pressure and heart rate changes}

Mean arterial blood pressure and heart rate were monitored in all studied animals using a PowerLab system (ADInstruments, Colorado Springs, USA). Under isoflurane anesthesia, a catheter was inserted into the left common carotid artery and exteriorized in the interscapular region, the animal was put into a prone position and a balloon compression lesion or transection was performed. Mean arterial pressure $(\mathrm{mm} \mathrm{Hg}$ ) and heart rate (bpm) were monitored for 5 min before the spinal compression, throughout the entire injury procedure and for $10 \mathrm{~min}$ after spinal decompression. After the initial rise in blood pressure following the injury procedure, we observed a break point in the descending curve, which was termed the ,turning point“".

The values obtained were: 1) the baseline value, i.e. the value before the inflation of the balloon, 
Table 2. The thickness of the alveolar wall $(\mu \mathrm{m})$ in the lungs of animals with either a balloon compression lesion (rapid or graded) or a spinal cord transection and control groups.

\begin{tabular}{lc}
\hline \multicolumn{1}{c}{ Group } & Thickness of alveolar wall $(\boldsymbol{\mu m})$ \\
\hline NPE model & $94.18 \pm 4.37 *$ \\
$(15 \mu l)$ & $(+161 \%)$ \\
$5-5-5 \mu l$ & $62.61 \pm 4.17 *$ \\
& $(+71 \%)$ \\
$3-2-2-2-2-2-2 \mu l$ & $38.62 \pm 2.12$ \\
& $(+5 \%)$ \\
Immediate $5 \mu l$ & $37.32 \pm 2.94$ \\
& $(+2 \%)$ \\
Immediate $10 \mu l$ & $35.99 \pm 1.95$ \\
& $(-2 \%)$ \\
Spinal & $39.63 \pm 3.02$ \\
transection & $(+8 \%)$ \\
Control & $36.71 \pm 2.57$ \\
\hline
\end{tabular}

Statistical significance from control rats is denoted by an asterisk $(p<0.05)$. Control animals are animals without spinal cord injury, sacrificed immediately after the onset of anesthesia. Relative changes from controls are shown in parentheses.

2) the maximum value after inflation with a particular volume with respect to the experimental group $(3,5,7$, $9,10,11,13,15 \mu \mathrm{l}), 3)$ the average value between the peak after the inflation to $15 \mu \mathrm{l}$ and the turning point, and 4) the average value between the turning point and deflation of the balloon.

\section{Statistical analysis}

The pulmonary index, mean arterial pressure and heart rate are reported as mean values \pm S.E.M. The statistical significance $(\mathrm{p}<0.05)$ between groups was compared using the non-paired Student's t-test. The differences within the groups were examined using the paired Student's t-test $(\mathrm{p}<0.05)$.

\section{Results}

The spinal cord lesioning procedure was performed in all animals without any unexpected complications. The inflation of the balloon to $15 \mu \mathrm{l}$ was accompanied by skeletal muscle contractions in all cases, which was considered as a normal reaction to injury and was in accordance with our previous observations (Syková et al. 2005, Syková and Jendelová 2006, Urdziková et al. 2006). In addition, a blood pressure increase acompanied the balloon inflation in all cases (Šedý et al. 2007a).
Table 3. Baseline values of mean arterial pressure as well as the values found after a particular degree of balloon inflation in rats with different rate of induction of balloon compression lesion.

\begin{tabular}{|c|c|c|c|}
\hline & \multicolumn{3}{|c|}{ Mean arterial pressure (mm $\mathbf{H g})$} \\
\hline & $\begin{array}{c}\text { NPE } \\
\text { model } \\
15\end{array}$ & $\begin{array}{c}\text { Rapid } \\
5-5-5\end{array}$ & $\begin{array}{c}\text { Slow } \\
\text { 3-2-2-2-2-2-2 }\end{array}$ \\
\hline $\begin{array}{l}\text { Baseline } \\
\text { values }\end{array}$ & $85 \pm 6$ & $97 \pm 4$ & $97 \pm 2$ \\
\hline $3 \mu l$ & - & - & $\begin{array}{l}108 \pm 4 * \\
(+11 \%)\end{array}$ \\
\hline $5 \mu l$ & - & $\begin{array}{l}113 \pm 6^{*} \\
(+16 \%)\end{array}$ & $\begin{array}{l}130 \pm 6^{*} \\
(+34 \%)\end{array}$ \\
\hline $7 \mu l$ & - & - & $\begin{array}{l}141 \pm 6^{*} \\
(+45 \%)\end{array}$ \\
\hline $9 \mu l$ & - & - & $\begin{array}{l}143 \pm 5 * \\
(+47 \%)\end{array}$ \\
\hline $10 \mu l$ & - & $\begin{array}{l}153 \pm 6^{*} \\
(+58 \%)\end{array}$ & - \\
\hline $11 \mu l$ & - & - & $\begin{array}{l}147 \pm 5^{*} \\
(+52 \%)\end{array}$ \\
\hline $13 \mu l$ & - & - & $\begin{array}{l}148 \pm 4 * \\
(+53 \%)\end{array}$ \\
\hline $15 \mu l$ & $\begin{array}{l}154 \pm 7 * \\
(+81 \%)\end{array}$ & $\begin{array}{l}155 \pm 3 * \\
(+60 \%)\end{array}$ & $\begin{array}{l}150 \pm 4 * \\
(+55 \%)\end{array}$ \\
\hline $\begin{array}{c}15 \mu l- \\
\text { turning } \\
\text { point }\end{array}$ & $\begin{array}{l}144 \pm 6^{*} \\
(+69 \%)\end{array}$ & $\begin{array}{l}138 \pm 3 * \\
(+42 \%)\end{array}$ & $\begin{array}{l}133 \pm 3^{*} \\
(+37 \%)\end{array}$ \\
\hline $\begin{array}{c}\text { Turning } \\
\text { point- } \\
\text { deflation }\end{array}$ & $\begin{array}{l}86 \pm 5 \\
(+1 \%)\end{array}$ & $\begin{array}{l}90 \pm 4 \\
(-7 \%)\end{array}$ & $\begin{array}{l}97 \pm 3 \\
( \pm 0 \%)\end{array}$ \\
\hline
\end{tabular}

Statistically significant (paired Student's t-test, $p<0.05$ ) differences from baseline values are marked with an asterisk. Relative changes as a percentage of baseline values are shown in parentheses.

The immediate inflation of the balloon in the spinal channel to $15 \mu \mathrm{l}$ caused severe neurogenic pulmonary edema in all cases. The extent of subpleural bleeding, the pulmonary index, the thickness of the alveolar walls as well as the blood pressure and heart rate values (Tables 1, 2 and 3; Fig. 1) corresponded to the values observed previously for this model of severe neurogenic pulmonary edema (Šedý et al. 2007b).

Slow balloon inflation prevented neurogenic pulmonary edema development

When the balloon was slowly inflated in small 

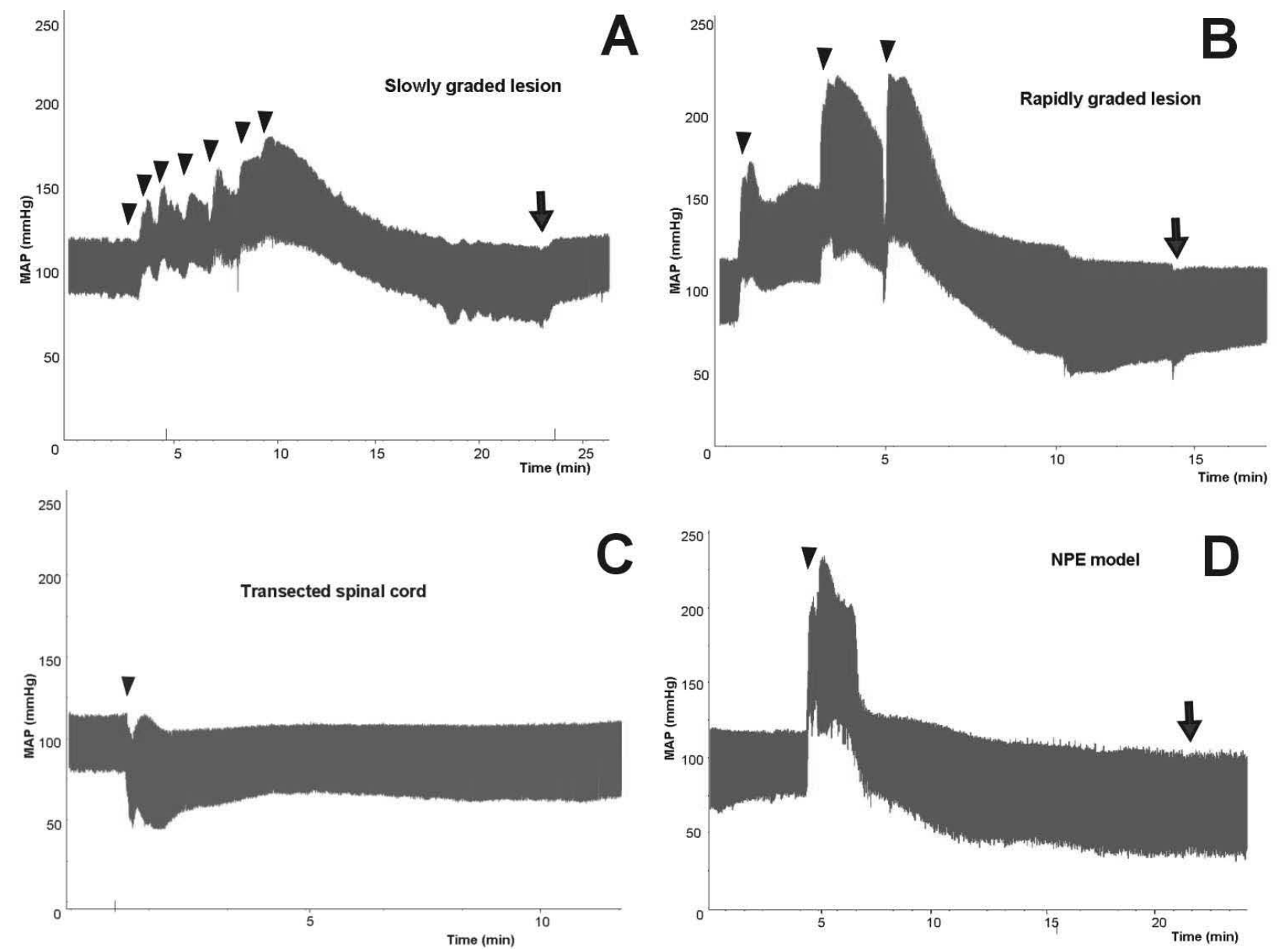

Fig. 1. The time course of blood pressure before, during and after the balloon inflation in the spinal channel to a final volume of $15 \mu \mathrm{l}$. Each inflation step is indicated by an arrowhead in A,B and D. Arrows show the balloon deflation in A, B and D. A. Slowly graded balloon compression lesion. B. Rapidly graded balloon compression lesion. C. The time course of blood pressure before, during and after spinal cord transection (arrowhead). D. The time course of blood pressure in the model of neurogenic pulmonary edema (immediate balloon inflation).

steps $(3 \mu \mathrm{l}-2 \mu \mathrm{l}-2 \mu \mathrm{l}-2 \mu \mathrm{l}-2 \mu \mathrm{l}-2 \mu \mathrm{l}-2 \mu \mathrm{l})$, neurogenic pulmonary edema did not develop. In $64 \%$ of cases, subpleural bleeding was absent. In the remaining cases, there was Grade I subpleural bleeding (Table 1). In addition, the pulmonary index and the mean thickness of the alveolar walls did not differ significantly from control values (Tables 1 and 2). The histological appearance of the lung tissue was comparable to that of the controls there were almost no signs of intraalveolar or interstitial edema or hemorrhage (Fig. 2). Moreover, the mean thickness of the alveolar wall was not significantly increased (Table 2).

Neurogenic pulmonary edema after rapid balloon inflation

Although the final volume of the inflated balloon was the same as in the previous case, the rapid inflation (5 $\mu \mathrm{l}-5 \mu \mathrm{l}-5 \mu \mathrm{l}$ ) of the balloon caused a severe neurogenic pulmonary edema, comparable to that seen in the standard neurogenic pulmonary edema model. The occurrence of Grade III subpleural bleeding was not so frequent as in our neurogenic pulmonary edema model, but the extent of the bleeding was always at least Grade II (Table 1). Similarly, the pulmonary index values in the rapid inflation group did not differ significantly from the values obtained in our neurogenic pulmonary edema model. On the other hand, the pulmonary index values of rapid inflation group were significantly increased when compared with controls $(p<0.0001)$. Microscopic examination of the lungs showed that the rapid inflation of the balloon caused edema of the alveolar membrane, perforation of thin capillary walls, massive bleeding and the leakage of intravascular fluid into the alveoli - a typical picture of neurogenic pulmonary edema (Fig. 2C). Moreover, the mean thickness of the alveolar walls in the rapidly inflated group was significantly higher when compared to controls (Table 2). 


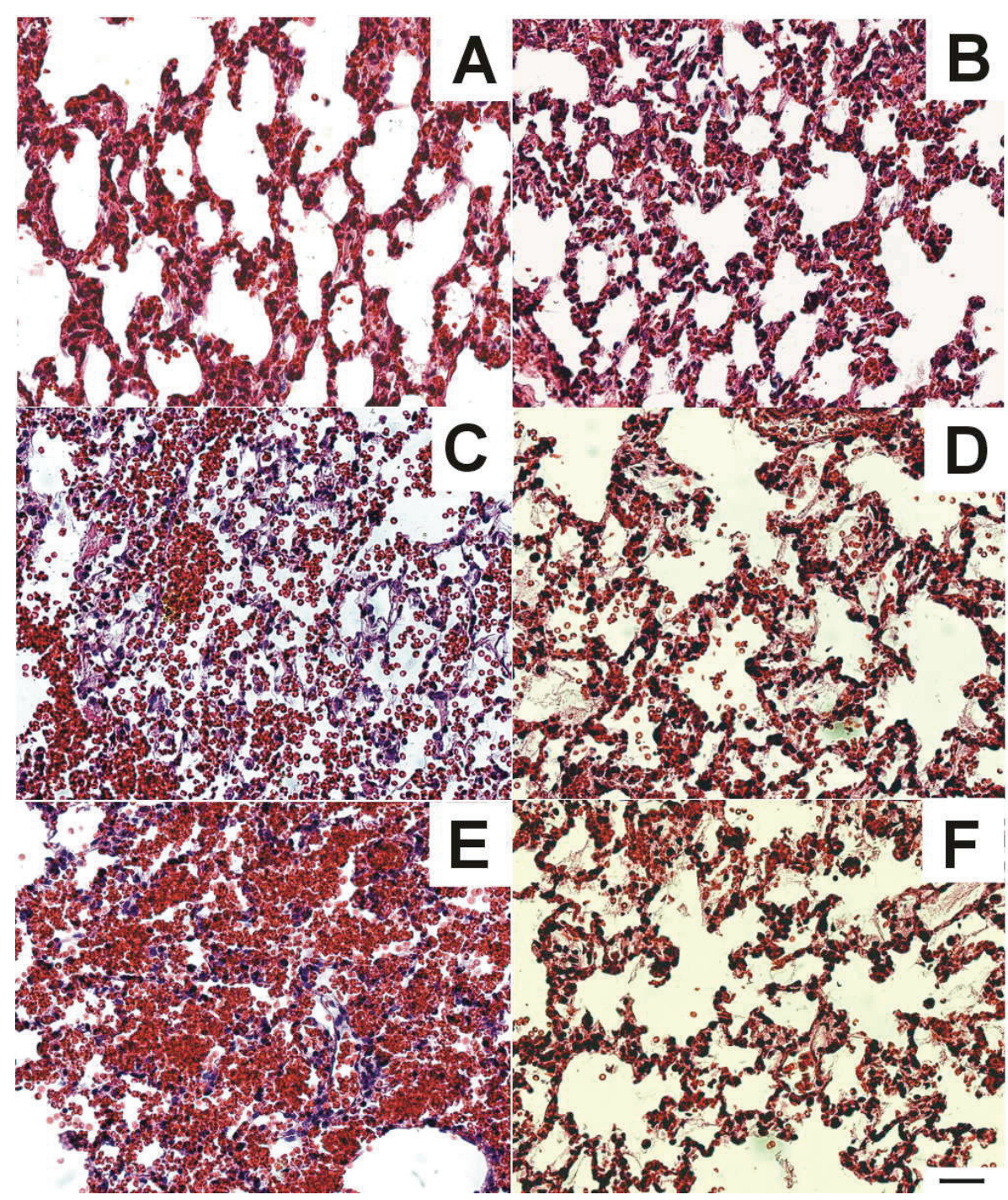

Fig. 2. Pulmonary histological changes in animals with graded compression lesions or spinal cord transection. A. Occasional bleeding areas without evident pulmonary edema in a rat with a slowly graded balloon compression lesion. B. Occasional bleeding areas without evident pulmonary edema in a rat with a moderately graded balloon compression lesion. C. Histology showing a massive neurogenic pulmonary edema with a thickening of the alveolar walls, interstitial edema and massive bleeding in a rat with a rapidly graded balloon compression lesion. D. Histology of lungs in animals with a spinal cord transection. No signs of pulmonary edema are present. E. Histology showing a massive neurogenic pulmonary edema with a thickening of the alveolar walls, interstitial edema and massive bleeding in a rat with neurogenic pulmonary edema. F. Histology of the lungs of a control animal. Scale bar in $\mathrm{F}=200 \mu \mathrm{m}$.
Blood pressure and heart rate changes during different rates of balloon inflation

All steps of the graded balloon inflation procedure were accompanied by a significant elevation of the mean arterial pressure (Table 3 ). The graded lesion was accompanied by a typical ascendently undulating mean arterial pressure curve (Fig. 1). No significant differences in mean arterial pressure values during and after the inflation of the balloon to the final volume of $15 \mu \mathrm{l}$ were observed among the slowly and rapidly inflated groups (Table 3), although the differences in the degree of neurogenic pulmonary edema were highly significant (Table 1).

The extent of neurogenic pulmonary edema was more reflected by the changes of heart rate. In the rapidly inflated group (with NPE), there was a pronounced decrease in heart rate during the whole balloon inflation procedure, whereas in the slowly and moderately inflated groups, a mild transient heart rate decrease was observed
(Table 4). Moreover, the heart rate changes after the maximum balloon inflation to $15 \mu$ were more prominent in the rapidly than in the slowly inflated groups (Table 4). Taken together, the more rapid the balloon inflation, the more pronounced the decrease in heart rate during and after the inflation.

Incomplete balloon inflation prevented neurogenic pulmonary edema

The inflation of the balloon to $10 \mu \mathrm{l}$ was accompanied by mild skeletal muscle contractions, the inflation to $5 \mu \mathrm{l}$ caused almost none reaction. The immediate inflation of the balloon in the spinal channel to either $5 \mu \mathrm{l}$ or $10 \mu \mathrm{l}$ did not cause neurogenic pulmonary edema. No animal from $5 \mu \mathrm{l}$ or $10 \mu \mathrm{l}$ group had subpleural bleeding (Table 1). Moreover, the mean pulmonary index and alveolar wall thickness of these animals were comparable to controls (Tables 1 and 2). 
Table 4. Baseline values of heart rate as well as the values found after a particular degree of balloon inflation in three different groups with a graded balloon compression lesion during the induction of the lesion.

\begin{tabular}{|c|c|c|c|}
\hline & \multicolumn{3}{|c|}{ Heart rate (bpm) } \\
\hline & $\begin{array}{l}\text { NPE } \\
\text { model }\end{array}$ & $\begin{array}{c}\text { Rapid } \\
\text { 5-5-5 }\end{array}$ & $\begin{array}{c}\text { Slow } \\
\text { 3-2-2-2-2-2-2 }\end{array}$ \\
\hline $\begin{array}{c}\text { Baseline } \\
\text { values }\end{array}$ & $385 \pm 9$ & $380 \pm 14$ & $410 \pm 5$ \\
\hline $3 \mu l$ & - & - & $\begin{array}{c}384 \pm 11 \\
(-6 \%)\end{array}$ \\
\hline $5 \mu l$ & - & $\begin{array}{c}364 \pm 16^{*} \\
(-4 \%)\end{array}$ & $\begin{array}{c}383 \pm 7^{*} \\
(-7 \%)\end{array}$ \\
\hline $7 \mu l$ & - & - & $\begin{array}{c}394 \pm 6 \\
(-4 \%)\end{array}$ \\
\hline $9 \mu l$ & - & - & $\begin{array}{c}394 \pm 8 \\
(-4 \%)\end{array}$ \\
\hline $10 \mu l$ & - & $\begin{array}{c}322 \pm 30^{*} \\
(-15 \%)\end{array}$ & - \\
\hline $11 \mu l$ & - & - & $\begin{array}{c}394 \pm 8 \\
(-4 \%)\end{array}$ \\
\hline $13 \mu l$ & - & - & $\begin{array}{c}391 \pm 8 \\
(-5 \%)\end{array}$ \\
\hline $15 \mu l$ & $\begin{array}{c}253 \pm 30^{*} \\
(-34 \%)\end{array}$ & $\begin{array}{c}222 \pm 23 * \\
(-42 \%)\end{array}$ & $\begin{array}{c}389 \pm 11^{\$} \\
(-5 \%)\end{array}$ \\
\hline $\begin{array}{c}15 \mu l- \\
\text { turning } \\
\text { point }\end{array}$ & $\begin{array}{c}313 \pm 21 * \\
(-19 \%)\end{array}$ & $\begin{array}{c}282 \pm \\
16^{*} \\
(-26 \%)\end{array}$ & $\begin{array}{c}371 \pm 10^{* \$} \\
(-10 \%)\end{array}$ \\
\hline $\begin{array}{c}\text { Turning } \\
\text { point - } \\
\text { deflation }\end{array}$ & $\begin{array}{c}361 \pm 11 \\
(-6 \%)\end{array}$ & $\begin{array}{c}336 \pm 15^{*} \\
(-12 \%)\end{array}$ & $\begin{array}{c}387 \pm 8 \\
(-6 \%)\end{array}$ \\
\hline
\end{tabular}

Statistically significant (paired Student's t-test, $p<0.05$ ) differences from baseline values are marked with an asterisk. Significant differences (un-paired Student's t-test, $p<0.05$ ) from the NPE model are marked with \$. Relative changes as a percentage of baseline values are shown in parentheses.

Spinal transection did not cause neurogenic pulmonary edema

Transection of the spinal cord at the same spinal level as the balloon compression lesion did not cause neurogenic pulmonary edema. Subpleural bleeding was absent in all animals and the pulmonary index was comparable to that of the controls. Histology of the lung tissue did not reveal any sign of neurogenic pulmonary edema (Fig. 2D, Table 2). Spinal cord transection did not cause any blood pressure or heart rate disturbances; in particular, there was no sharp increase in blood pressure as typically seen after balloon inflation (Fig. 1).

\section{Discussion}

We have shown that a slow rate of balloon inflation in the thoracic epidural space prevented the development of neurogenic pulmonary edema. This was indicated by the absence of significant subpleural bleeding as well as by an increase in the pulmonary index and mean alveolar wall thickness. Similarly, incomplete ( 5 or $10 \mu \mathrm{l}$ ) balloon inflation or spinal transection at the same level did not cause neurogenic pulmonary edema. The differences in NPE development were accompanied by characteristic changes of heart rate. Rats with NPE had a considerably decreased heart rate after the inflation of the balloon to the final $15 \mu \mathrm{l}$ volume compared to rats without edema, in which heart rates were similar to baseline values (Table 4).

The development of neurogenic pulmonary edema seems to be based on the hyperactivity of the sympathetic system, in terms of a severe sympathetic discharge, also called a catecholamine storm (Dragosavac et al. 1997, Fontes et al. 2003, Leal Filho et al. 2005a,b). When a ganglionic blockade is performed by pentolinium, administered before spinal cord lesioning, neurogenic pulmonary edema does not develop (Šedý et al. 2007a). Our experiments indicate that slower inflation of the balloon in the epidural space is able to prevent NPE development, probably due to the easier adjustment of the organism to gradual hemodynamic changes over a longer time period. Poulat and Couture (1998) showed that the intrathecal injection of endothelin-1 causes the activation of the endothelin receptor in sympathetic spinal neurons. Their activation subsequently causes a sympathetic discharge, a massive release of catecholamines, intense pulmonary alpha-adrenergic vasoconstriction, an increase in pulmonary vascular permeability and pulmonary edema. One explanation of our results might be that a slowly graded spinal cord lesion leads to the release of small amounts of vasoactive substances to which the systemic and pulmonary circulation are able to adjust, whereas the release of these substances in the NPE model is so rapid that the circulation is unable to adjust.

Another hypothesis suggests that the inflation of the balloon in the epidural space causes a rapid increase in intracranial pressure, which leads to the stimulation of sympathetic "neurogenic pulmonary edema trigger zones" in the bottom of the fourth ventricle (Baumann et al. 2007, Leal Filho et al. 2005a, b, Šedý et al. 2008a,b). During the slow inflation of the balloon in the epidural 
space, the intracranial space has a longer time to "adapt" to these changes. Moreover, after each of the subsequent balloon inflation steps, the cerebrospinal fluid might "leak" around the incompletely obstructed spinal channel. This probably does not happen when the balloon is inflated rapidly - from our previous studies we know that only $5 \%$ of the spinal cord tissue is spared at the site of the lesion, while the rest of the spinal channel is obstructed by the balloon during the inflation, when the balloon is inflated to $15 \mu \mathrm{l}$ (Urdziková et al. 2006, Syková et al. 2005, Syková and Jendelová 2006, Šedý et al. 2007a). The lack of neurogenic pulmonary edema in animals with a transected thoracic spinal cord indirectly supports such a hypothesis.

Our results indicate that the final volume of the balloon is also very important for the development of neurogenic pulmonary edema. To induce neurogenic pulmonary edema in animals anesthetized with $1.5 \%$ isoflurane, the balloon must be inflated to the final $15 \mu \mathrm{l}$, because the inflation to $10 \mu \mathrm{l}$ or less does not cause it. Importantly, this volume-based impairment corresponds to the neurological deficit caused by Th8 epidural ballon inflation. Vanický et al. (2001), who developed the epidural balloon spinal cord compression model, reported that inflation of the balloon to $10 \mu \mathrm{l}$ caused mild neurological deficit, which recovered to normal values of BBB locomotor score in few weeks. We observed that the inflation of the balloon to $5 \mu \mathrm{l}$ caused almost no neurological deficit next day and it recovered to normal values of BBB next week after the surgery in all cases (Šedý, Jendelová, Syková, unpublished observation). On the other hand, during the experiments published in our first paper concerning the role of isoflurane anesthesia on NPE development (Šedý et al. 2007a), we also inflated the balloon to $20 \mu \mathrm{l}$ in both groups, anesthetized either with $1.5 \%$ isoflurane or $3 \%$ isoflurane. The results were comparable to those obtained in animals in which a final volume of the balloon was set to $15 \mu \mathrm{l}$ (Šedý, Urdziková, Jendelová, Syková, unpublished observation). This indicates that in $1.5 \%$ isoflurane group (with NPE) the neurogenic pulmonary edema can not be further augmented, even when we inflate the balloon to $20 \mu \mathrm{l}$.

Rapid balloon inflation is associated with major sympathetic activation leading to blood redistribution from splanchnic vessels to the pulmonary vascular bed and with a pronounced rise of systemic blood pressure, causing a heart rate decrease due to baroreflex activation (Šedý et al. 2007a,c). In our experiments, the systemic blood pressure increase in rats with a slowly inflated balloon (without NPE) did not cause pronounced baroreflex activation. Conversely, in rats with a rapidly inflated balloon (causing NPE), the threshold was exceeded and the baroreflex turned on, so that the reduction in the heart rate could limit the capacity of the heart to pump blood from the pulmonary vascular bed to the systemic circulation.

\section{Conclusions}

A slow rate of balloon inflation in the thoracic epidural space prevents the development of neurogenic pulmonary edema, most likely due to the adaptation of the organism to enhanced sympathetic tone and consequent cardiovascular reactions (blood volume redistribution, blood pressure increase, baroreflex activation) during the longer balloon inflation period. Spinal cord transection at the same level does not cause neurogenic pulmonary edema.

\section{Conflict of Interest}

There is no conflict of interest.

\section{Acknowledgements}

We thank Dominika Dušková and Iva Nahodilová for their excellent technical assistance. We thank James Dutt for critical reading of the manuscript. We acknowledge the support provided by the grants AV0Z50390512, AV0Z50110509, 1M0538, LC554, GACR309/06/1246, IGA MZ 1A8697-5, IGA MZ NR/8339-3, 1M0510 and the EC FP6 project RESCUE (LSHB-CT-2005-518233).

\section{References}

BASSO DM, BEATTIE MS, BRESNAHAN JC: A sensitive and reliable locomotor rating scale for open field testing in rats. J Neurotrauma 12: 1-21, 1995.

BAUMANN A, AUDIBERT G, MCDONNEL J, MERTES PM: Neurogenic pulmonary edema. Acta Anaesthesiol Scand 51: 447-455, 2007.

CAMBRIA RP, DAVISON JK, ZANNETTI S: Clinical experience with epidural cooling for spinal cord protection during thoracic and thoracoabdominal aneurysm repair. J Vasc Surg 25, 234-241, 1997. 
DRAGOSAVAC D, FALCAO ALE, ARAÚJO S, TERZI RGG: Neurogenic pulmonary edema: report of two cases. Arq Neuropsiquiatr 55: 305-309, 1997.

FONTES RB, AGUIAR PH, ZANETTI MV, ANDRADE F, MANDEL M, TEIXEIRA MJ: Acute neurogenic pulmonary edema: case reports and literature review. J Neurosurg Anesthesiol 15: 144-150, 2003.

KANDATSU N, NAN YS, FENG GG, NISHAWAKI K, ISHIKAWA K, KOMATSU T, YOKOCHI T, SHIMADA Y, ISHIKAWA N: Opposing effects of isoflurane and sevoflurane on neurogenic pulmonary edema development in an animal model. Anesthesiology 102: 1182-1189, 2005.

KONDO H, FENG GG, NISHIWAKI K, SHIMADA Y, HIROKAWA M, KOMATSU T, YOKOCHI T, ISHIKAWA $\mathrm{N}$ : A role for L-glutamate ionotropic receptors in the development of rat neurogenic pulmonary edema. Eur $J$ Pharmacol 499: 257-263, 2004.

LEAL FILHO MB, MORANDIN RC, DE ALMEIDA AR, CAMBIUCCI EC, METZE K, BORGES G, GONTIJO JA: Hemodynamic parameters and neurogenic pulmonary edema following spinal cord injury: an experimental model. Arq Neuropsiquiatr 63: 990-996, 2005a.

LEAL FILHO MB, MORANDIN RC, DE ALMEIDA AR, CAMBIUCCI EC, BORGES G, GONTIJO JA, METZE K: Importance of anesthesia for the genesis of neurogenic pulmonary edema in spinal cord injury. Neurosci Lett 373: 165-170, 2005b.

MESQUITA MB, MORAES-SANTOS T, MORAES MF: Phenobarbital blocks the lung edema induced by centrally injected tityustoxin in adult Wistar rats. Neurosci Lett 332: 119-122, 2002.

MINNEAR FL, CONNELL RS: Increased permeability of the capillary-alveolar barriers in neurogenic pulmonary edema (NPE). Microvasc Res 22: 345-366, 1981.

POULAT P, COUTURE R: Increased pulmonary vascular permeability and oedema induced by intrathecally injected endothelins in rat. Eur J Pharmacol 344: 251-259, 1998.

ŠEDÝ J, URDZIKOVÁ L, HEJČL A, BURIAN M, LIKAVČANOVÁ K, JENDELOVÁ P, ZICHA J, KUNEŠ J, SYKOVÁ E: Low concentration of isoflurane promotes the development of neurogenic pulmonary edema in spinal cord injured rats. J Neurotrauma 24: 1487-1501, 2007a.

ŠEDÝ J, URDZIKOVÁ L, LIKAVČANOVÁ K, HEJČL A, JENDELOVÁ P, SYKOVÁ E: A new model of severe neurogenic pulmonary edema in spinal cord injured rats. Neurosci Lett 423: 167-171, $2007 \mathrm{~b}$.

ŠEDÝ J, URDZIKOVÁ L, HEJČL A, BURIAN M, LIKAVČANOVÁ K, JENDELOVÁ P, SYKOVÁ E: Low concentration of isoflurane causes neurogenic pulmonary edema in spinal cord injured rats. Physiol Res 56: 34P, 2007c.

ŠEDÝ J, LIKAVČANOVÁ K, URDZIKOVÁ L, ZICHA J, KUNEŠ J, HEJČL A, JENDELOVÁ P, SYKOVÁ E: Low degree of anesthesia increases the risk of neurogenic pulmonary edema development. Med Hypotheses 70: 308313, 2008a.

ŠEDÝ J, ZICHA J, KUNEŠ J, JENDELOVÁ P, SYKOVÁ E: Mechanism of neurogenic pulmonary edema development. Physiol Res 57: 499-506, 2008 b.

SYKOVÁ E, JENDELOVÁ P: Magnetic resonance tracking of transplanted stem cells in rat brain and spinal cord. Neurodegener Dis 3: 62-67, 2006.

SYKOVÁ E, URDZIKOVÁ L, JENDELOVÁ P, BURIAN M, GLOGAROVÁ K, HÁJEK M: Bone marrow cells - A tool for spinal cord injury repair. Exp Neurol 193: 261-262, 2005.

TAOKA Y, OKAJIMA K: Spinal cord injury in the rat. Prog Neurobiol 56: 341-358, 1998.

URDANETA F, LAYON AJ: Respiratory complications in patients with traumatic cervical spine injuries: case report and review of the literature. J Clin Anesth 15: 398-405, 2003.

URDZIKOVÁ L, VANICKÝ I: Post-traumatic moderate systemic hyperthermia worsens behavioural outcome after spinal cord injury in the rat. Spinal Cord 44: 113-119, 2006.

URDZIKOVÁ L, JENDELOVÁ P, GLOGAROVÁ K, BURIAN M, HÁJEK M, SYKOVÁ E: Transplantation of bone marrow stem cells as well as mobilization by granulocyte - colony stimulating factor promote recovery after spinal cord injury in rat. $J$ Neurotrauma 23: 1379-1391, 2006.

VANICKÝ I, URDZIKOVÁ L, SAGANOVÁ K, ČİŽKOVÁ D, GÁLIK J. Simple and reproducible model of spinal cord injury induced by epidural baloon inflation of the rat. J Neurotrauma 18: 1399-1407, 2001. 